\title{
PHOTOGRAMMETRIC MEASUREMENTS OF HERITAGE OBJECTS
}

\author{
E. Tumeliene ${ }^{1}$, V. Nareiko ${ }^{1}$, J. Suziedelyte Visockiene ${ }^{1 *}$ \\ ${ }^{1}$ VGTU, Environmental Engineering Faculty, 10223 Vilnius, Lithuania - egle.tumeliene@vgtu.lt; vnareiko.lt@gmail.com; \\ jurate.visockiene@vgtu.lt
}

Commission V, WG V/7

KEY WORDS: Historical images, Photogrammetry, 3D modelling, Cultural Heritage

\begin{abstract}
:
Cultural heritage is an invaluable example of human culture and creativity. The majority of them can become unstable or can be destroyed due to a combination of human and natural disturbances. In order to restore, preserve, and systematize data about architectural heritage objects, it is necessary to have geodetic, photogrammetric measurements of such data and to constantly monitor condition of the objects. The data of immovable cultural objects for many years are stored in photogrammetric data archives. Such archives have Germany, Lithuania, England and other countries. The article gives a brief introduction of the history of data archives formation and presents a photogrammetric and modern methods of modelling the spatial geometric properties of objects currently used to reveal immovable cultural properties and to evaluate geometric sizes. The pilot work was done with the Concept Capture simulation program that was developed by the Bentley company with photos of the Blessed Virgin Mary painting in Pivašiūnai of Trakai district. A shot from the ground with 12.4 MP resolution Pentax K-x camera was done using lenses with different focal lengths. The painting of the Blessed Virgin Mary is coordinated by 4 reference geodesic points and therefore after the modelling work it was possible to evaluate the accuracy of the created model. Based on the results of the spatial (3D) model, photo shooting and modelling recommendations are presented, the advantages of the new technology are distinguished.
\end{abstract}

\section{INTRODUCTION}

\subsection{History of heritage objects documentation}

Geometric information about immovable cultural heritages is very important and can be collected from geodetic measurements by using theodolite or total station, by performing photogrammetric measurements from subject photogrammetric images, by using laser scan data or even by using remote sensing. In Europe, photogrammetric recording of valuable architectural monuments and the accumulation of their data in the archives began in 1858 (Albertz, 2001).

In Germany, engineer and also architect Albrecht Meydenbauer, proposed to photograph buildings and to make façade plans from the received photographs according with a certain methodology. This offer was recognized only after 27 years. In 1885, the Institute of Photogrammetry was founded in Prussia, led by A. Meydenbauer. His main goal was to create a photogrammetric archive of valuable architectural monuments. On the same problem work has been done not only in Europe but also in Asian countries (India, Persia, etc.). Until 1914 in Germany, 2000 buildings were photographed and 16400 photographs were taken. After decades, the material has gained invaluable cultural-historical value. Most of the negatives are unique as historical documents, and the A. Meydenbauer archive itself - as a technical and cultural monument.

In 1919 the Military Aviation Service was established in Lithuania, and in 1924, a part of the topography was established as a section of the Lithuanian Armed Forces General Staff which in 1929 has grown to the Military Topography Division of the Ministry of National Defence. This organization carried out the main photogrammetric works in Lithuania. Brigade general Stasys Dirmantas (1887-1975) presented the first information about aerial images in Lithuania. In 1923 the first one wrote the textbook "Topography" in the Lithuanian language, in which was presented the essence of the aerial photograph and examples of photographs (Razinskas, 2000).

Jonas Deksnys (1904-1989) first started the application of aerial imagery in Lithuania (Girkus, 2000). He actively promoted this. He was first to read a photogrammetric course at the university. Trained by him and later active aerial geodesists A. Žalnierukas (associate prof. At Vilnius Gediminas Technical University) and V. Vainauskas (Prof. at Vilnius Gediminas Technical University) took over many of his ideas. He probably was the first who used the possibilities of using a colour photo in Lithuania (Girkus et al., 2000). Since 1970, material for the photogrammetric archive has been accumulated in Lithuania. Since then, in the spring-autumn months, photogrammetric images of valuable architectural monuments are made, and in winter periods this material is systematized and handled. In addition, topographic images of the environment objects are made and details of the interior of the building being measured by using geodesic methods. The material of the photogrammetric archive is stored in the archives of the Lithuanian National Land Service and the Land Fund, and currently established Lithuanian Spatial Information Portal under Ministry of Agriculture provide it for free. All objects of cultural heritage are included in the Lithuanian cultural property register and their descriptions, and the works performed are easily found in the information system (https://kvr.kpd.lt/\#/).

"Cultural Heritage Imaging" (CHI), a non-profit organization based in San Francisco, is working to create rules, technologies, and training that help preserve historical, cultural and artistic values (http://culturalheritageimaging.org). CHI uses photographic techniques based on the work of researchers at the United States Office of Land Management (BLM) who have

\footnotetext{
* Corresponding author
} 
been developing their photogrammetric techniques for about 20 years (Lynch et al 2016, 2017). The method allows the creation of a photogrammetric data set that is independent from the software and can provide the fullest possible data which can be read by other software that exist on the market. The model of a properly obtained photogrammetric data set is the same as a 3D model created with high-quality special software.

Ukraine, like other countries, has many immovable cultural heritages. We can be glad that the agreement between the government of Ukraine and the government of the Republic of Poland signed in 1992 on cultural and scientific cooperation provide opportunities for cooperation in the field of cultural heritage protection. The article shows how it was to establish a historical and architectural reserve in Zhovska in 1992 (Herych, 2014). Cooperation has been ongoing so far.

Strategies currently used for architectural heritage documentation are based on the spatial data acquisition techniques such as conventional surveying, laser scanning, photogrammetry or combination all methods (Grussenmeyer et al., 2008; Sužiedelytė-Visockienè et al., 2015).

\subsection{Photogrammetric measurements of heritage objects}

Photogrammetry can play an important role thanks to the large available historical and current photographic imageries, which offers the advantage of a monitoring over time, both in qualitative and quantitative terms: in fact, the use of images acquired in the past (through the so-called "archival" or "historical" photogrammetry) allows to make comparisons and multi-temporal analysis, supported by metric data (Bitelli et al., 2017). Also, advantage of photogrammetric measurements spatial, accurate model of object, when elements of façade of the building can be obtained in $3 \mathrm{D}$ coordinate system (we have $\mathrm{X}$. Y, Z coordinates). The 3D model requires two overlapping photographs and several reference points, the coordinates of which are measured by the geodetic method (by using theodolite or a total station). The process of photogrammetric measurements includes the following complex tasks ((see Figure 1) (Sužiedelytė-Visockienè et al., 2015): Digital Image Capturing processes:

- Photogrammetric processing of the images

- Accuracy and quality control.

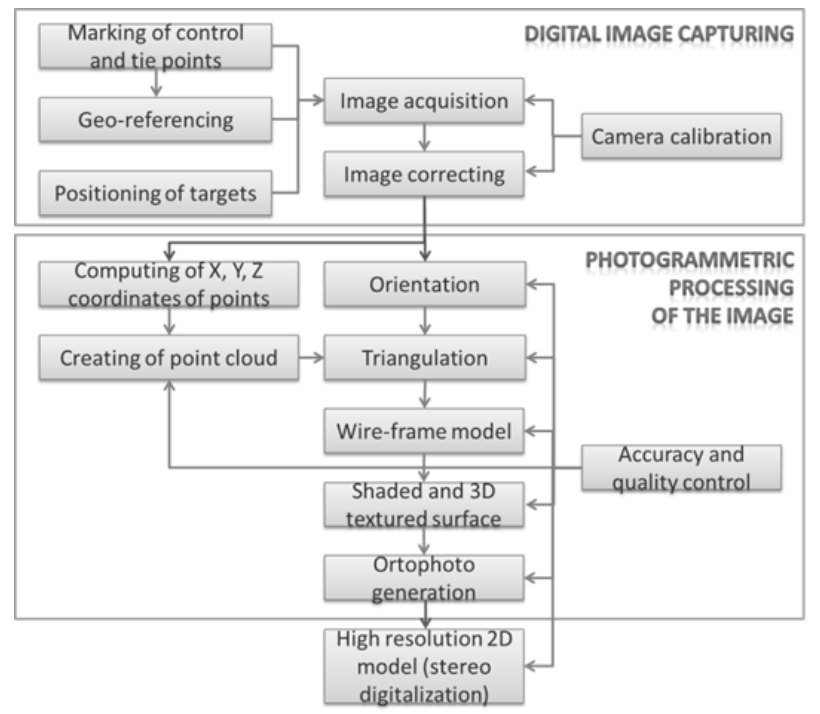

Photogrammetry involves steps that are performed in an automated or manual way, but it also demands a professional expertise when depending on project type and conditions user's interaction and intervention is required at specific stages of the modelling pipeline (Sužiedelytè-Visockienè et al., 2015). Manual procedures are still necessary for accurate element extraction from the satellite, aerial or terrestrial image. Predominantly automated methods are becoming increasingly available to cultural heritage community. They can be used effectively for visualization, object-based navigation, annotation or image browsing (Vergauwen et al., 2006; Remondino, 2011). It is important to understand that not only photogrammetric or traditional investigation can be used for monitoring of heritage objects. Cultural heritage sites, referring to the locations of historical structures and monuments such as ancient palaces, churches, tombs and bridges, are rare, irreversible and irreplaceable wealth of humanity. Unfortunately, they are often impacted by natural calamities and anthropogenic activities. The former includes landslides, earthquakes, floods, adverse weather and abrupt climate change (Panpan Tangn, Fulong Chen, Xiaokun Zhu, Wei Zhou. 2016). Generally, structural and ground instabilities can be jointly triggered by the subtle, long-term movements at the mm-level due to natural erosions, ground displacements or crust movements. Abrupt deformations due to drastic events such as earthquakes, landslides and impacts of war may cause more significant, i.e., at least cm-level, shifts (Zhou, W.; Chen, F.L.; Guo, H.D, 2015.).

Traditional investigations, including levelling, GPS surveying and geophysical prospecting are restricted by their limited spatial/temporal coverage as well as the need for considerable human and financial resources. Furthermore, some of the traditional approaches are invasive, such as installing electrical sensors in structures for data acquisition (Zhou, W.; Chen, F.L.; Guo, H.D, 2015.).

Multi-Temporal Interferometric Synthetic Aperture Radar (MTInSAR) techniques (e.g., Persistent Scatters (PSInSAR), Small BAseline Subsets (SBAS), and SqueeSAR), rely on processing of multi-temporal repeat-pass SAR images to measure phase signals of radar targets. They overcome the shortcomings of traditional methods referred to above and provide a framework for large-scale and high-precision (from $\mathrm{cm}$ to $\mathrm{mm}$ level) deformation monitoring (Panpan Tangn, Fulong Chen, Xiaokun Zhu, Wei Zhou. 2016).

\subsection{OBJECT RECONSTRUCTION PROCESS}

\subsection{General introduction}

Object from which 3D model is obtained, can be captured by various geodetic instruments or systems, such as (Cho et al., 2013; Colomina et al., 2014; Ding et al. 2015; Suziedelyte Visockienè et al 2016; Xu et al. 2014): Scanners, Total Stations, Digital Cameras, Non-Pilot Aircraft and Satellite Systems (Figure 2).
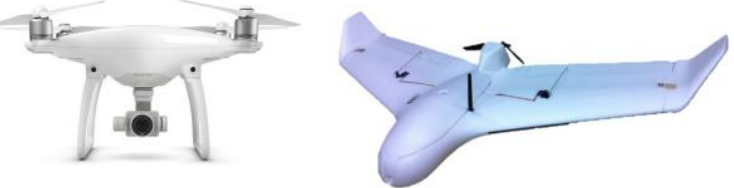

Figure 1. Pipeline for digital image capturing and photogrammetric processing 

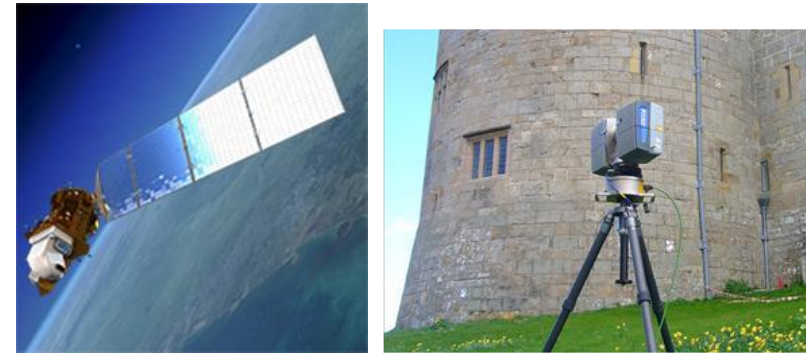

Figure 2. Technical equipment

A schematic diagram of the classic photographic processing received from various sources is presented in Figure 3. Photogrammetric image processing methods are primarily developed and applied in the fields of image acquisition (sensor technology, calibration), pre-processing and segmentation (image measuring, line following, image matching). Major consideration for these methods are the automation of relatively simple repetitive measuring tasks and the achievement of appropriate measurement accuracy (Luhman et al., 2006).

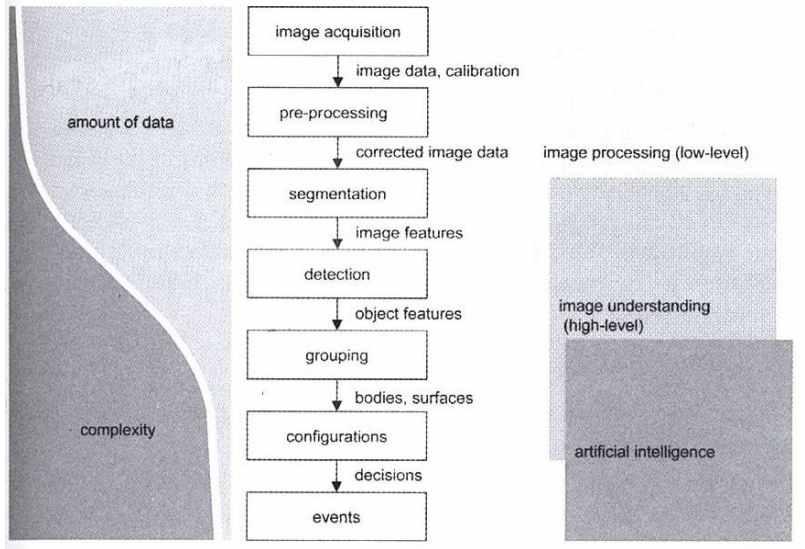

Figure 3. Image processing sequence (Luhman et al., 2006)

With digital technology improvements, most of photogrammetric processes, such as cameras optics calibration, photo orientation, triangulation calculation, orthophotography and 3D image generation, are already automated. Not only professional, but also amateur or even integrated camera in mobile phones can be used for shooting the subject, and taking pictures without complying with strict photogrammetric shooting rules. The quality of the resulting 3D models will depend on the quality of the input images and their spatial configuration. For high quality images are recommended:

- A constant focal length during the acquisition: zoom "with your feet";

- A constant and homogeneous lighting.

You should avoid:

- Blurry images: use adapted settings, and possibly a tripod under low lighting conditions.

- Flash light;

- Optical stabilization.

You must banish:

- Digital zoom,

- Any resizing/cropping/rotation of the input photos (turn off your camera's auto-rotation mode),

- Fish-eye lenses.
The expected 3D result accuracy can be calculated according to the following formula:

$$
\begin{aligned}
& R=\frac{L_{S} \times D}{c \times L}, \\
& P=3 \times R,
\end{aligned}
$$

where $\quad \mathrm{c}=$ focal length of the camera $(\mathrm{mm})$

$L_{S}=$ the greater size of the sensor $(\mathrm{mm})$

$D=$ the distance between the camera and the subject

(m) (m/Pixel)

$L=$ the greater size of the photograph (in Pixel)

$\mathrm{R}=$ the spatial ground resolution of the photos in of the 3D mesh.

$P=$ the precision of spatial positioning of the vertices

Because $L_{S}$, c and $L$ are usually fixed from a using camera, the only way to improve accuracy is to decrease the flight height. This will also result in taking more images to cover the same area. $P$ is the relative precision of the $3 \mathrm{D}$ mesh. The absolute precision of 3D model only make sense if it is geo-referenced. The model can be geo-referenced by using the position of the images or by adding ground control points with known geodetic coordinates.

\section{EXPERIMENTAL RESULTS AND ACCURACY}

\subsection{Experimental objects}

The Virgin Mary Assumption Parish Church that stand on the high hill in Pivašiūnai is a monument of wooden sacral architecture of Lithuania (Kaišiadorys parish). The Latin Crossshaped church is simple, but at the same time artistically distinct (http://www.pivasiunai.lt ) (Figure 4).

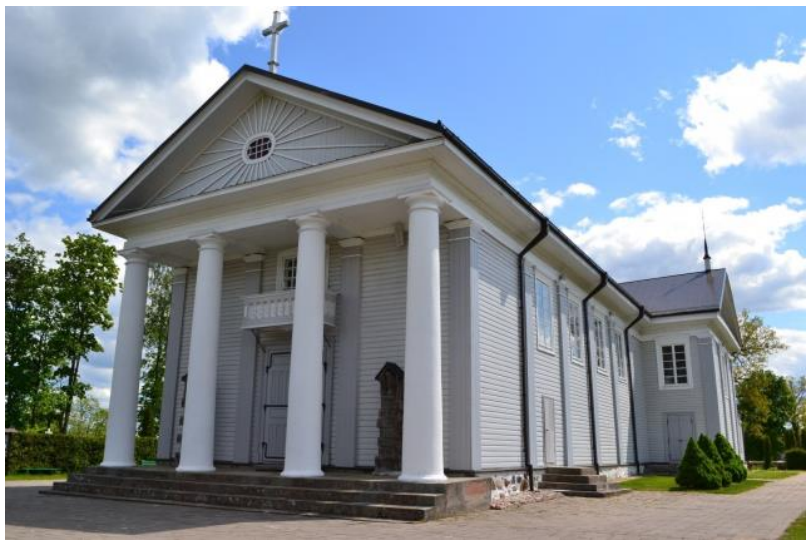

Figure 4. The Virgin Mary Assumption Parish Church of Pivašiūnai

The titles given to the Church reflect the special devotion of the Mother of God, the respect of the Blessed Virgin Mary. John the Baptist, the patron saint of the first sponsor Jonas Klokieris, and St. Benedict, the Benedictine Father and the main conqueror of the Western Monastery. As the traditions of this devotion are reflected in the works of art of Pivašiūnai Church, the art historian Regimanta Stankevičienè examines in great detail in the report "The Benedictine Art Heritage in Pivašiūnai 
Church" (Stankevičienė, 2008). This church is a historical site of Lithuanian religion and culture, which contains many valuable sacred objects. A book about the sacred paintings and objects contained in the Pivašiūnai Church was published on the 80th anniversary of the Kaišiadorys diocese (Poligienè, 2006). Scientists of the Department of Geodesy and Cadaster of the Vilnius Gediminas Technical University, together with specialists of the scientific production company UAB "Cad and F ProjektServisas", photographed the methodology of the 17thcentury unknown artist of Lithuania in Pivašiūnai Church. photogrammetrical measurements and drawing works of the picture of the Holy Mother of God with the Baby in the middle of the day. The article presents the results of these works.

\subsection{Photogrammetric measurements of "Mother of God" painting}

Photogrammetric measurements of the painting were done in 2008 on a digital basis by PhotoMod (Russia) photogrammetric work system according to the technology presented in section 1.2. A digitalised vector image - a two-dimensional (2D) model is required for storing the object data and in case of need for restoration. (Figure 5).

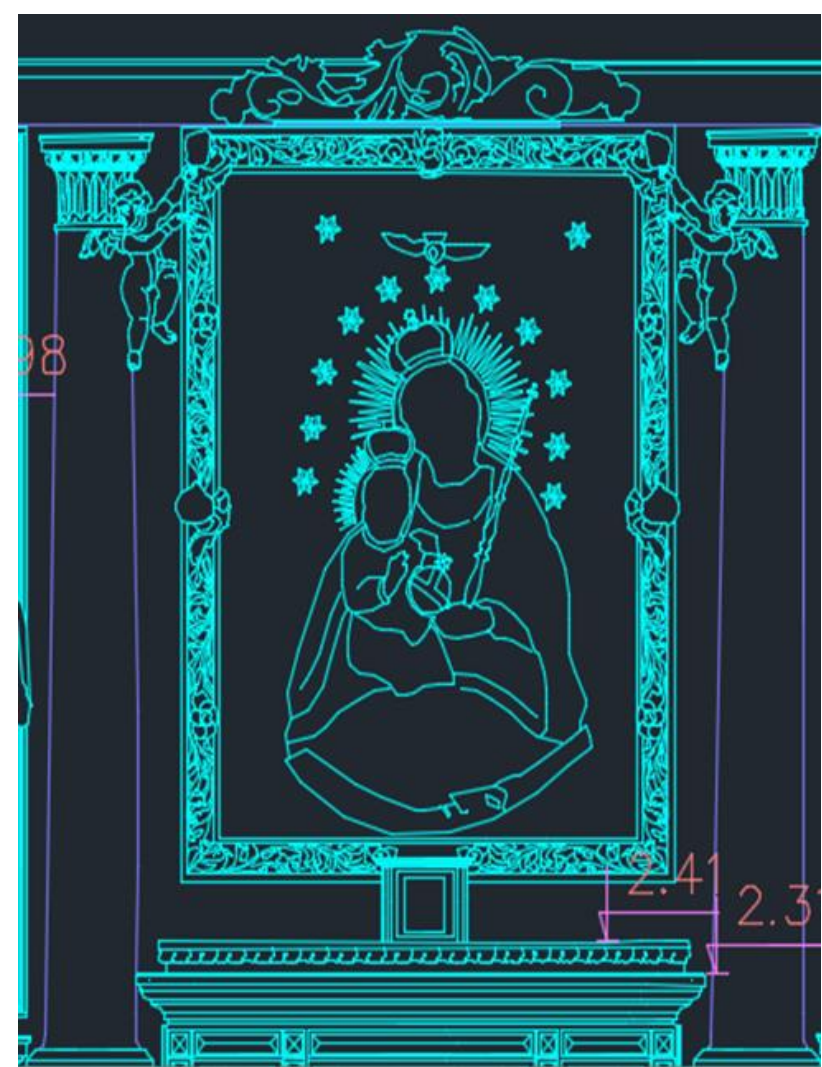

Figure 5. 2D model of painting created by using photogrammetry

In 2016, the work of the restoration of the "Mother of God" painting started. God's Mother's robe and picture frame is covered with expensive gold and silver coat. For restoration, the new 3D modelling technology (sub-section 2.1) is used to estimate the amount of material, because the 2D model can only determine the area of the object in the plane without taking into account the surface curvature. High-resolution picture taken with Canon and Pentax digital cameras with different focal length lenses. 23 interlaced photographs have been captured. (Figure 6).
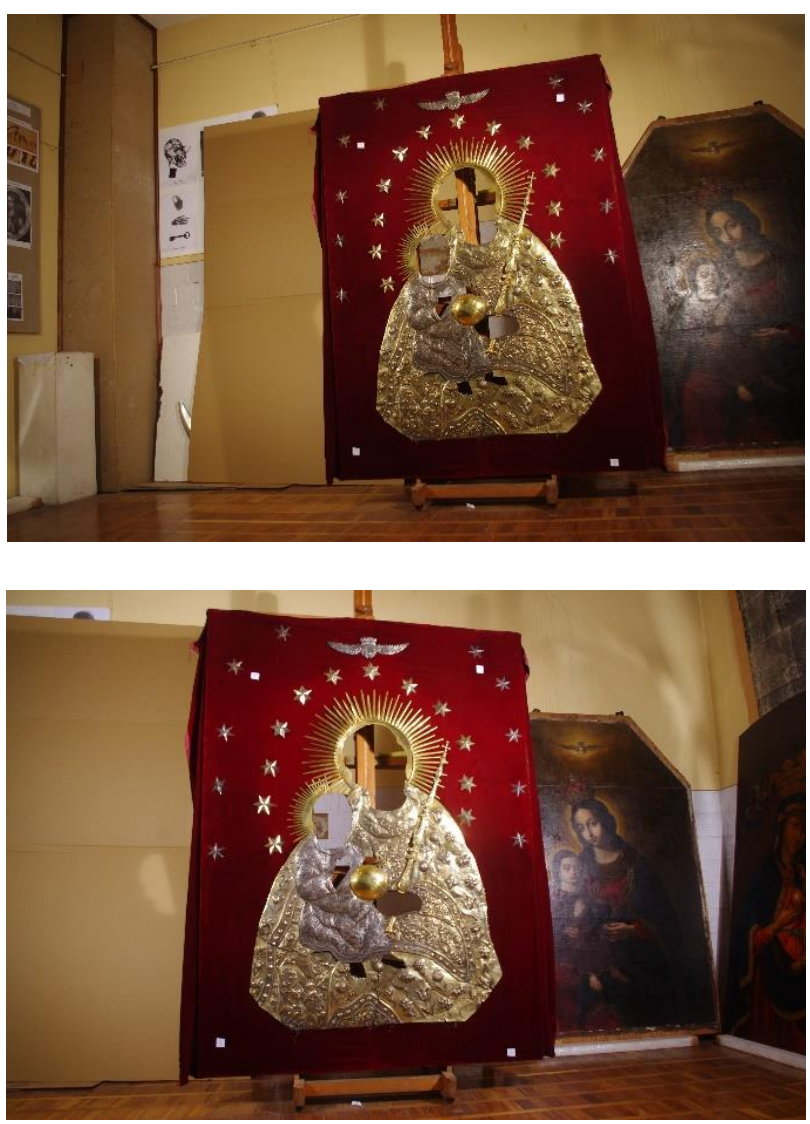

Figure 6. Example of images

For getting true size of painting, measurements of 4 points was done with geodetic equipment - total station (Figure 7).

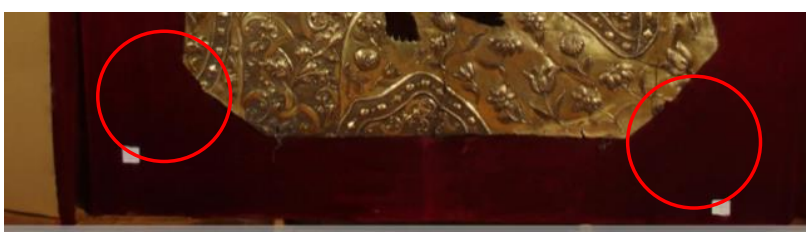

Figure 7. Geo-reference points

The Context Capture (Bentley) program automatically selects points of connection, which where coordinated by reference points into geodetic coordinate system. Work was done much faster than using classical photogrammetric methods. 3D model of the base of the God's Mother's painting generated by images is provided in Figure 8. 


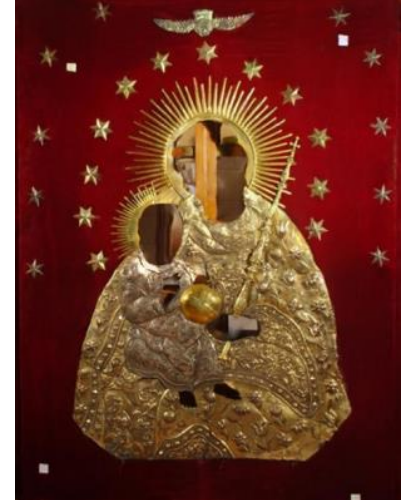

a)

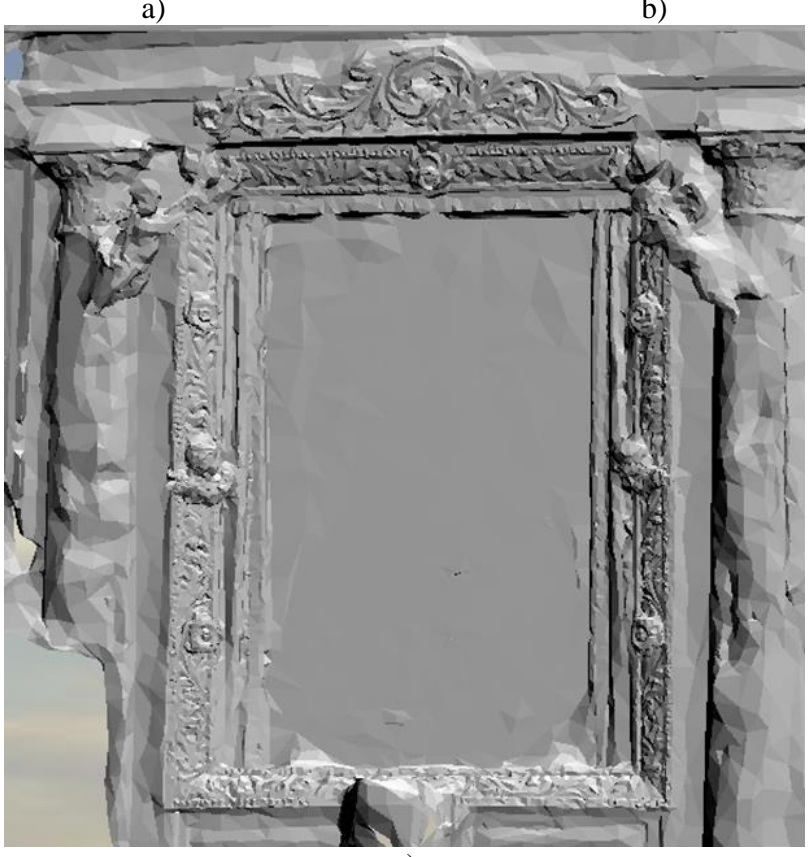

c)

Figure 8. Implemented 3D model: a) 3Dmodel; b) 3D base surface pattern; c) 3D frame surface texture

Measurements was done on the surface of the painting by taking into account the relief. Calculation of surface was done by removing the hole. The surface of stars, the moon, the crown and other elements was calculated as well. The accuracy of the $3 \mathrm{D}$ model is evaluated by comparing the results of measuring and calculating the base points. The difference in reference points is only $1 \mathrm{~mm}$. This result highlights the high quality of the new 3D technology model.

\section{CONCLUSIONS AND FUTURE WORK}

After applying photogrammetric measurements and after photo image processing by created methodology, a 3D model of "Mother of God" painting was done. Measurements were done on the surface of the painting by taking into account the relief and image processing was done with PhotoMod program. The accuracy of the 3D model was evaluated by comparing the results of measuring and calculating the base points. The difference between reference and measured points is $1 \mathrm{~mm}$ that gives us high quality 3D model that can be briefly used for restoration work of the "Mother of God" painting. The new 3D technology can be used for documenting, monitoring or restoration works of heritage sites that are invaluable as human culture and creativity.

\section{REFERENCES}

Albertz, M., 2001. Report on the Proceedings 18th International Symposium CIPA "Albrecht Meydenbauer - pioneer of photogrammetric documentation of the cultural heritage", Potsdam, Germany http://www.hasler.net/Meydenb.pdf $18-21$ Sep. 2001).

Bitelli, G.; Dellapasqua, M.; Girelli, V.A.; Sbaraglia, S.; Tini, M.A., 2017. Historical photogrammetry and terrestrial laser scanning for the 3D virtual reconstruction of destroyed structures: a case study in Italy. The International Archives of the Photogrammetry, Remote Sensing and Spatial Information Sciences, Volume XLII-5/W1, 2017 GEOMATICS \& RESTORATION - Conservation of Cultural Heritage in the Digital Era, 22-24 May 2017, Florence, Italy https://www.intarch-photogramm-remote-sens-spatial-inf-sci.net/XLII-5W1/113/2017/isprs-archives-XLII-5-W1-113-2017.pdf

Cho, G.; Hildebrand, A.; Claussen, J.; Cosyn, P.; Morris, S. 2013. Pilotless aerial vehicle systems: size, scale and functions. Coordinates, vol. 9, no. 1, p. 8-16

Colomina, I.; Molina, P. 2014. Unmanned aerial systems for photogrammetry and remote sensing: a review. ISPRS Journal of Photogrammetry and Remote Sens-ing, vol. 92, p. 79-97.

Ding, L.; Wu, H.; Yao, Y. 2015. Chaotic artificial bee colony algorithm for system identification of a small-scale unmanned helicopter. International Journal of Aerospace Engineering, vol. 2015, Article ID801874, 11 pages.

Girkus, R.; Mockienė, D. Book "Inžinierius geodezininkas Jonas Deksnys (1904-1989) (Engineer Syrveyes of Jonas Deksnys (1904-1989)", http://www.mockus.us/optimum/deksnys/st_deksnys.html

Grussenmeyer, P.; Landes, T.; Voegtle, T.; Ringle, K. 2008. Comparison methods of terrestrial laser scanning, photogrammetry and tacheometry data for recording of cultural heritage buildings, International Archives of Photogrammetry, Remote Sensing and Spatial Information Sciences, 37, 213-218

Herych, V. 2014. Polish - Ukrainian cooperation concerning cultural heritage protection on the example of the city of Zhovska (Ukraine). Journal Barometr Regionalny Tom $12 \mathrm{Nr}$. 4. http://br.wszia.edu.pl/zeszyty/pdfs/br38_08herych.pdf

Luhman, T.; Robson, S.; Kyle, S.; Harley, J. 2006. Book "Close Range Photogrammetry. Principles, methods and applications", Published by Whittles Publishing, Scotland, UK.

Lynch, E.; Mattheus, N.A.; Noble, T. A. 2016. Unraveling the enigma of prehistoric bedrock ground stone features on the Chaquaqua Plateau, using close-range photogrammetry. Article in Quaternary International . March 2017, DOI: 10.1016/j.quaint.2017.02.012.

Lynch, E.; Mattheus, N.A.; Noble, T. A. 2017. Unraveling the enigma of prehistoric bedrock ground stone features on the Chaquaqua Plateau, using close-range photogrammetry. Article in Quaternary International March 2017, DOI: 10.1016/j.quaint.2017.02.012 
Poligienè, S. 2006. Kaišiadorių vyskupija ir jos sakralinis paveldas (albumas) (Diocese of Kaišiadorys and its sacred heritage (album). Book ISBN 9986-420-69-5.

Ražinskas, A. 2000. Book "Lietuvos geodezijos ir kartografijos istorija (History of Geodesy and Cartography in Lithuania)". Kaunas, Lithuania.

Remondino F.; Rizzi A.; Barazzetti L.; Scaioni M.; Fassi F.; Brumana R.; Pelagotti A. 2011. Review of geometric and radiometric analyses of paintings, Photogrammetric Record, 26, 439-461.

Stankevičienè, R. 2008. Benediktinų Dailès Paveldas Pivašiūnu Bažnyčioje (ang. the Benedictines' artistic heritage at Pivašiūnai Church). Article in Vilnius: Aidai.

Sužiedelytė-Visockienė, Jūratė; Bagdžiūnaitė, Renata; Malys Naglis; Maliené Vida. 2015. Close-range photogrammetry enables documentation of environment-induced deformation of architectural heritage. Environmental engineering and management journal. Iasi: "Gheorghe Asachi" Technical University of Iasi, Romania. ISSN 1582-9596. Vol. 14, no. 6 (2015), p. 1371-1381.

Sužiedelytè-Visockienè, J.; Puzienè, R.; Stanionis, A.; Tumelienè, E. 2016. Unmanned aerial vehicles for photogrammetry: analysis of orthophoto images over the territory of Lithuania. International Journal of Aerospace Engineering, vol. 2016, Article ID 4141037, 9 pages.

Vergauwen, M.; Van Gool, L. 2006, Web-based 3D reconstruction service, Machine Vision and Applications, 17, 411-426.

Xu, Y.; Sun, W.; Li, P. 2014. A miniature integrated navigation system for rotary-wing unmanned aerial ve-hicles. International Journal of Aerospace Engineering, vol. 2014, Article ID 748940, 13 pages.

Panpan, Tangn; Fulong, Ch.; Xiaokun, Z.; Wei, Z. 2016. Monitoring Cultural Heritage Sites with Advanced MultiTemporal InSAR Technique: The Case Study of the Summer Palace. Remote Sens, 8, 432, www.mdpi.com/20724292/8/5/432/pdf

Zhou, W.; Chen, F.L.; Guo, H.D, 2015. Differential radar interferometry for structural and ground deformation monitoring: A new tool for the conservation and sustainability of cultural heritage sites. Sustainability, 7, 1712-1729. 